\title{
CONTRIBUTION OF TROUT YOLK-SAC FRY (SALMO TRUTTA L.) ORIGINATING FROM WILD STOCK TO FISHING IN THE MOSELOTTE RIVER, FRANCE
}

\author{
D. GERDEAUX (1), J.F. LUQUET (2), A. POUPART (1), C. TOSTIVINT (1)
}

\author{
1 INRA Station d'hydrobiologie lacustre, 74203 Thonon, \\ Courriel: gerdeaux@thonon.inra.fr \\ 2 Délégation Régionale du CSP, 23, rue des Garennes, 57155 Marly, \\ Courriel: jean-francois.luquet@csp.ecologie.gouv.fr
}

\begin{abstract}
The Moselotte River has been severely affected by human activity and in some of its stretches this has impaired reproduction of trout, which has added to an adverse effect on the trout population arising from a high fishing pressure by local anglers. To offset this problem, the local anglers annually release about 50,000 yolk-sac fry that have been derived from wild native breeding stock. It was possible to monitor the fry released in 1999 and 2000 using a method of mass marking by immersion in a fluoromarking agent (Alizarin Red S). The trout enter the fishery at 3 years and about $90 \%$ of the trout caught are three or four years old. Fish that had been released represented $25.5 \%$ and $36.7 \%$ of the catches respectively in 2002 and 2003, two percentages that do not differ significantly. This proportion varied according to the location in the river. The age structure of the marked fish that were caught was similar to that of fish hatched in the wild.
\end{abstract}

Keywords: Salmo trutta, stocking, fluoromarking, otolith, yolk-sac fry.

\section{CONTRIBUTION Á LA PÊCHERIE DE DÉVERSEMENTS EN ALEVINS DE TRUITES (SALMO TRUTTA L.) Á VÉSICULE RÉSORBÉE ISSUS DE GÉNITEURS SAUVAGES AUTOCHTONES DANS LA MOSELOTTE (FRANCE)}

\section{RÉSUMÉ}

La rivière Moselotte, affluent vosgien de la Moselle, est relativement anthropisée et de ce fait impropre dans certains secteurs à une reproduction naturelle satisfaisante de la truite, d'autant que la pression de pêche est forte. Pour palier ce problème, les pêcheurs locaux déversent annuellement environ 50000 alevins issus de géniteurs sauvages autochtones, au stade vésicule résorbée. Le suivi des alevins déversés en 1999 et 2000 a été effectué grâce à une technique de marquage de masse par balnéation dans un fluoromarqueur. Les truites entrent dans la pêcherie au cours de leur troisième année de vie et environ $90 \%$ des truites pêchées sont dans leur troisième ou quatrième année. Les poissons alevinés contribuent aux captures pour 25,5\% en 2002 et pour 36,7 \% en 2003 , ces taux ne différent pas significativement. Cette contribution est variable suivant les secteurs. La structure en âge des poissons marqués capturés est similaire à celle des poissons issus de la reproduction naturelle. 
Mots-clés: Salmo trutta, alevinage, fluoromarquage, otolithe, alevin à vésicule résorbée.

\section{INTRODUCTION}

Stocking of brown trout (Salmo trutta L.) in order to boost or support existing wild populations that have been exposed to a deterioration of their habitat is commonly used in the management of rivers in France (THIBAULT, 1983) and elsewhere (COWX, 1994). Restoring the quality of the environment is now preferred and such stocking is carried out with caution. It is now possible to monitor the success of stocking on a relatively large scale since the development of fluoromarking methods, which make it possible to carry out mass marking by immersion of fry (TSUKAMOTO et al., 1989; NAGIEC et al., 1995; ECKMANN et al., 1998; BECKMAN and SCHULZ, 1996; CHAMPIGNEULLE and ROJAS BELTRAN, 2001; CAUDRON and CHAMPIGNEULLE, 2002, 2006). CHAMPIGNEULLE and ROJAS BELTRAN (2001) have successfully developed a protocol for marking the yolk-sac fry of trout by briefly immersing them in a solution of Alizarin Red $\mathrm{S}$, which results in a $100 \%$ marking rate.

Traditionally, anglers'clubs fishing in the rivers of the Vosges region, France, restock with yolk-sac fry bred from wild trout. This is done in order to compensate for any extra mortality of the fry due to spring floods (melting snow), in addition to combating anthropogenic impacts affecting spawning, especially the hydroelectric dams which are numerous in this area. The latter include long stretches of by-passed rivers, chanelisation and impassable weirs, all detrimental to the trout. In some locations, problems linked to the acidity of the water, as result of the underlying granite and acid rain, can also impact the local trout population (PROBST et al., 1990).

From 1998 to 2002, the Conseil Supérieur de la Pêche (CSP - the French Inland Fisheries and Water Council) together with local anglers, monitored the catches and analysed the fishing methods used in the area of the Cornimont Angling Association, corresponding to a stretch of about $13 \mathrm{~km}$ of the upper Moselotte River, in the Vosges region. This revealed that there was a considerable amount of fishing effort exploitation, and that the local anglers had very high CPUE, whatever their specific angling methods (MOUGENEZ, 2002; KLEIN, 2004). CPUE varied from 0.74 to more than 4 trout/hour for local anglers

In addition, a fluoromarking operation was carried out in order to determine the contribution of stocking to the catches and to the dynamics of the local trout populations. This operation involved marking the fry, sampling by the CSP of the caught trout, and then processing and analysing the sampled otoliths.

The marking experiment was carried out in 1999 and 2000, in order to mark all the yolk-sac fry released into the study area, a 13 kilometers stretch of the main stream of the Moselotte River.

As far as we are aware, this study is the first to be carried out on the fate of enhancement stocking with yolk-sac fry derived from wild trout in rivers that display a considerable degree of natural recruitment.

\section{MATERIALS AND METHODS}

\section{Study area}

The Moselotte River is a trout stream located in the granitic Vosges, a tributary flowing into the right bank of the Moselle, which takes its source high in the Vosges massif, beneath the Kastelberg mount, at an altitude of 1285 meters. Draining a catchment 
basin of $356 \mathrm{~km}^{2}$, it has a total length of $48 \mathrm{~km}$ and a mean slope gradient of $2 \%$. It flows through the small cities of La Bresse, and then Cornimont, where the present study took place (Figure 1). The water temperature varied between 0 and $17.2^{\circ} \mathrm{C}$ and the $\mathrm{pH}$ was between 6.5 and 6.6 .

The study area was divided into 6 sectors. Sectors 1-2-3 were on the main river; sector 4 was on a tributary (the Ventron Brook) with a less steep gradient. Sectors 5 and 6 were on another tributary, the Rouge Rupt brook, with more acid water ( $\mathrm{pH}$ 6.4) (NISBET, 1958; BOURRIÉ, 1978) (Table I). Reports on the trout population in the Moselotte and the fishery are available at www.csp.ecologie.gouv.fr.

\section{Table I}

Characteristics of the six different sectors of the study area.

\section{Tableau I}

Caractéristiques des 6 différents secteurs du site étudié.

\begin{tabular}{lcccccc}
\hline Sector & 1 & 2 & 3 & 4 & 5 & 6 \\
\hline Length $(\mathrm{m})$ & 1830 & 2020 & 2190 & 2490 & 3200 & 2000 \\
\hline Surface $\left(\mathrm{m}^{2}\right)$ & 27450 & 15615 & 12650 & 21990 & 17250 & 5000 \\
\hline Mean width $(\mathrm{m})$ & 15 & 7.7 & 5.8 & 8.8 & 5.4 & 2.5 \\
\hline
\end{tabular}

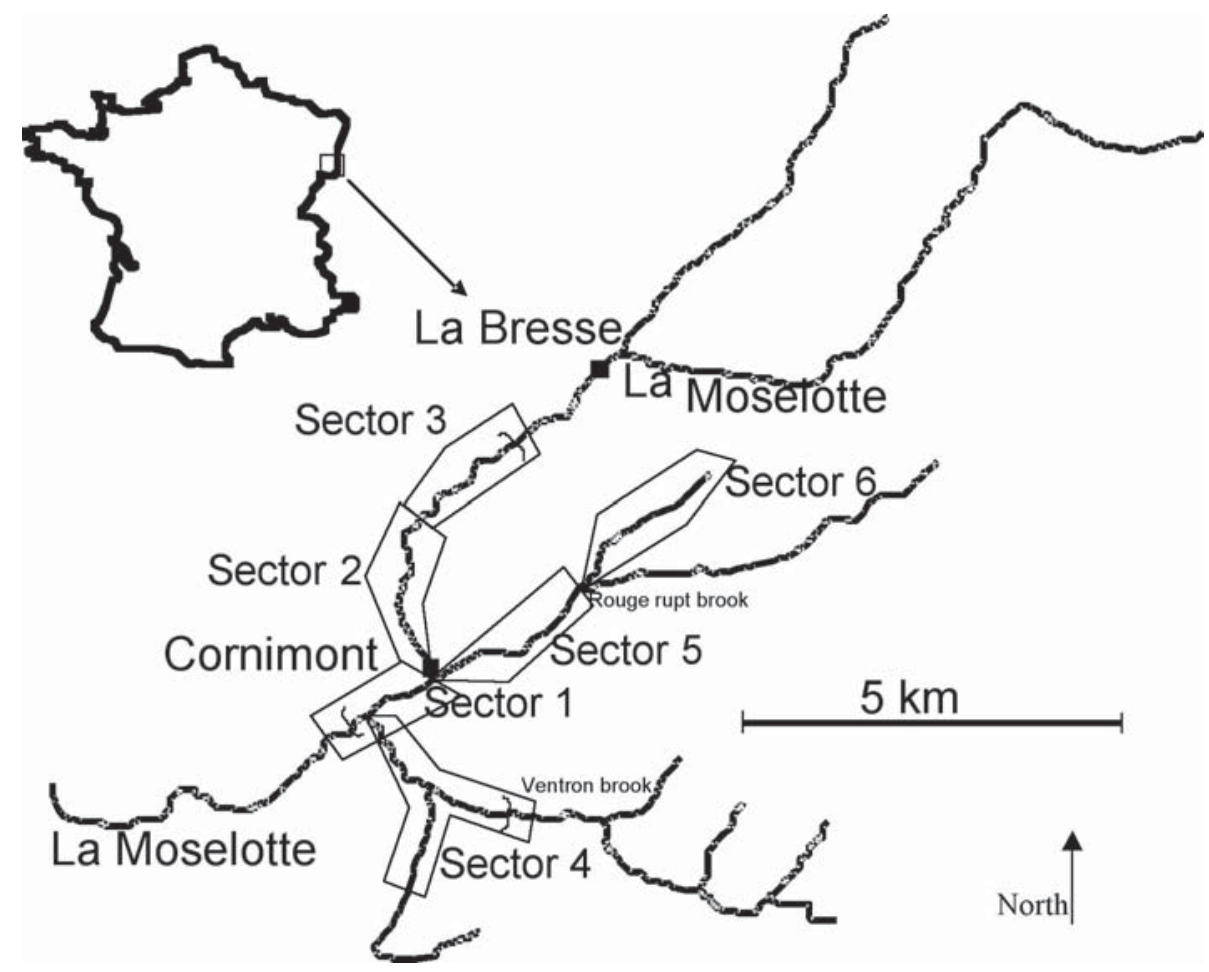

Figure 1

The study area.

Figure 1

Le site d'étude. 


\section{Stocking procedures}

The fry released into the studied sectors were hatched from eggs taken from wild trout (300 to 400 fish) that were caught in different ways. About $25 \%$ of the parent fish were obtained from anglers; from July on, volunteer anglers keep their best catches alive, and release them into a stream that flows into a former sawmill over a natural substrate, where they remain until artificial spawning in autumn. Most of the wild breeding stock was obtained by electric fishing carried out downstream of impassable barriers. In the autumn, the eggs were sampled and fertilized, and then incubated in an amateur hatchery set up by the anglers'association, which is water-fed by a tributary of the Moselotte River. The hatchery temperature regime was similar to that of the Moselotte River, so that the eggs and alevins developed at the same time as in the natural grounds. Once artificial spawning had taken place, the adult trout were released in the wild.

Fry were released when they reached the yolk sac stage directly after hatching. The releases took place from the beginning of April until the end of May in 1999, and from mid-April to mid-May in 2000. The stocked fish were released as batches, using a sieve or small landing net at places that the anglers thought would be suitable, and during the periods and flows thought to be the most favourable.

The mean stocking densities were 54 fry per $100 \mathrm{~m}^{2}$ in 1999, and about 41 fry per $100 \mathrm{~m}^{2}$ in 2000 (Table II). To some extent, the stocking densities took into account the sector's capacity to accommodate them and the fishing pressure estimated by the anglers.

\section{Table II}

Stocking densities (individuals $/ 100 \mathrm{~m}^{2}$ ) in each sector of the study.

\section{Tableau II}

Densités d'alevinage (individus $/ 100 \mathrm{~m}^{2}$ ) dans chaque secteur de l'étude.

\begin{tabular}{lcccccc}
\hline Sector & 1 & 2 & 3 & 4 & 5 & 6 \\
\hline 1999 & 46 & 44 & 110 & 43 & 49 & 30 \\
\hline 2000 & 18 & 40 & 85 & 41 & 39 & 24 \\
\hline
\end{tabular}

\section{Marking}

Fluoromarking was carried out by immersing the swimming fry in a solution of 300 $\mathrm{mg}$ of Alizarin Red S per litre for 2 hours $30 \mathrm{~min}$. The $\mathrm{pH}$ range was 6.4-6.8. The water was aerated continuously and its temperature was $6^{\circ} \mathrm{C}$. The fry were released 1 or 2 days after being marked, and any that had died or were dying after the procedure were discarded. The mortality was less than $1 \%$. Nothing was known on mortality due to fluoromarking after releasing. If there was some mortality, the consequence should be an underestimation of the contribution of stocking without any consequence on the conclusion of this work. Some of the yolk-sac fry released in 1998, 6,000 fry in all, had been marked and all the fry released in 1999 and 2000 were fluoromarked, i.e. 52,700 and 43,000 fry respectively. Some of the marked fry were released into a holding race connected to the river and caught again in the autumn. Out of the 14 fry checked in this way, 12 exhibited very clear marking. The two fry that were not marked were bigger and may have been bred naturally upstream from the race. We therefore assumed that the marking process had been totally effective. 


\section{Sampling the catches}

The study area is managed by only one angling association. The minimum legal size for catches is $20 \mathrm{~cm}$ in total length in the tributaries, and $23 \mathrm{~cm}$ in the main stream. Volunteer anglers keep records of their catches for the fishery survey. These anglers provided 197 trout in 2002 and 74 trout in 2003 for examination. The heads of these 271 trout were cut off and frozen before the otoliths were removed. For each fish, a sample of the scales was kept in an envelope and if necessary used to estimate the age of the fish by scalimetry. This sampling allowed appropriate survey of the total number of trout usually caught (the annual catch for the study area was previously estimated to be 3000 , CSP pers. comm.). The total length, weight, date and place of catch for each fish caught were also recorded.

\section{Analysis of the otoliths and scales}

Both otoliths (sagittae) were removed and one of them was mounted on a thin plate, convex side upwards, using a thermoadhesive heated to $120^{\circ} \mathrm{C}$ (Crystalbond 509 AREMCO). The otolith was then polished until the core was exposed. It was then examined under a Zeiss Axiolab microscope fitted with an epifluorescence mercury vapour lamp and a set of Zeiss $n^{\circ} 9$ filters (excitation blue 450-490, FT510, emission LP520).

The age of the trout was also estimated by examining the polished otolith and counting the number of lines corresponding to checks in growth in the winter under an Olympus BH-2 microscope. If this examination was not conclusive, the scales were also examined. For each fish examined, four scales were cleaned with a solution of sodium hypochlorite containing $0.5 \%$ active chlorine and mounted between two glass slides.

\section{Statistical analysis}

The statistical tests used to compare the proportion of trout marked, the age distribution, and the biometric measurements were the $\chi^{2}$ test, Student's t-test, KruskalWallis's test, Kolmogorov-Smirnov's test and Wilcoxon's test. These statistical tests were carried out using S-PLUS 6.0 (Insightful 2001).

\section{RESULTS}

\section{Length, weight and age structure}

Analysis of the length and weight data for all of the 267 trout collected during the years 2002 and 2003 showed that they had a mean length of $23.8 \mathrm{~cm}\left(\mathrm{Cl}_{95 \%} 23.6 \mathrm{~cm}\right.$ $24 \mathrm{~cm})$ and a mean weight of $132 \mathrm{~g}\left(\mathrm{Cl}_{95 \%} 128 \mathrm{~g}-135 \mathrm{~g}\right)$.

By convention, trout in their third year of life are described as " $2+$ ", those in their fourth year of life as " $3+$ " and those in the fifth year as " $4+$ ". The analysis of the otoliths and scales gave the following results concerning the structure in terms of age of this fraction of the trout caught in 2002 and 2003. In 2002, 57.4\% of the fish were $2+, 40.1 \%$ were $3+$ and $2.5 \% 4+$. In $2003,50 \%$ of the fish were $2+, 43.2 \%$ were $3+$ and $6.8 \% 4+$.

The histograms of the length distributions for each age group revealed significant differences in length and weight between the 2+, 3+ and 4+ fish (t-test, $\mathrm{P}<0.05$ ), (Figure 2). The $4+$ histogram is not shown, because the number of fish (10) was too small to permit a valid interpretation.

\section{Contribution of marked fry to anglers'catches in 2002 and 2003.}

$31.1 \%$ of the 271 fish sampled in the 2002 and 2003 catches had been marked $\left(\mathrm{Cl}_{95 \%}\right.$ 25.5\%-36.7\%). The marking rates were statistically significantly different between 


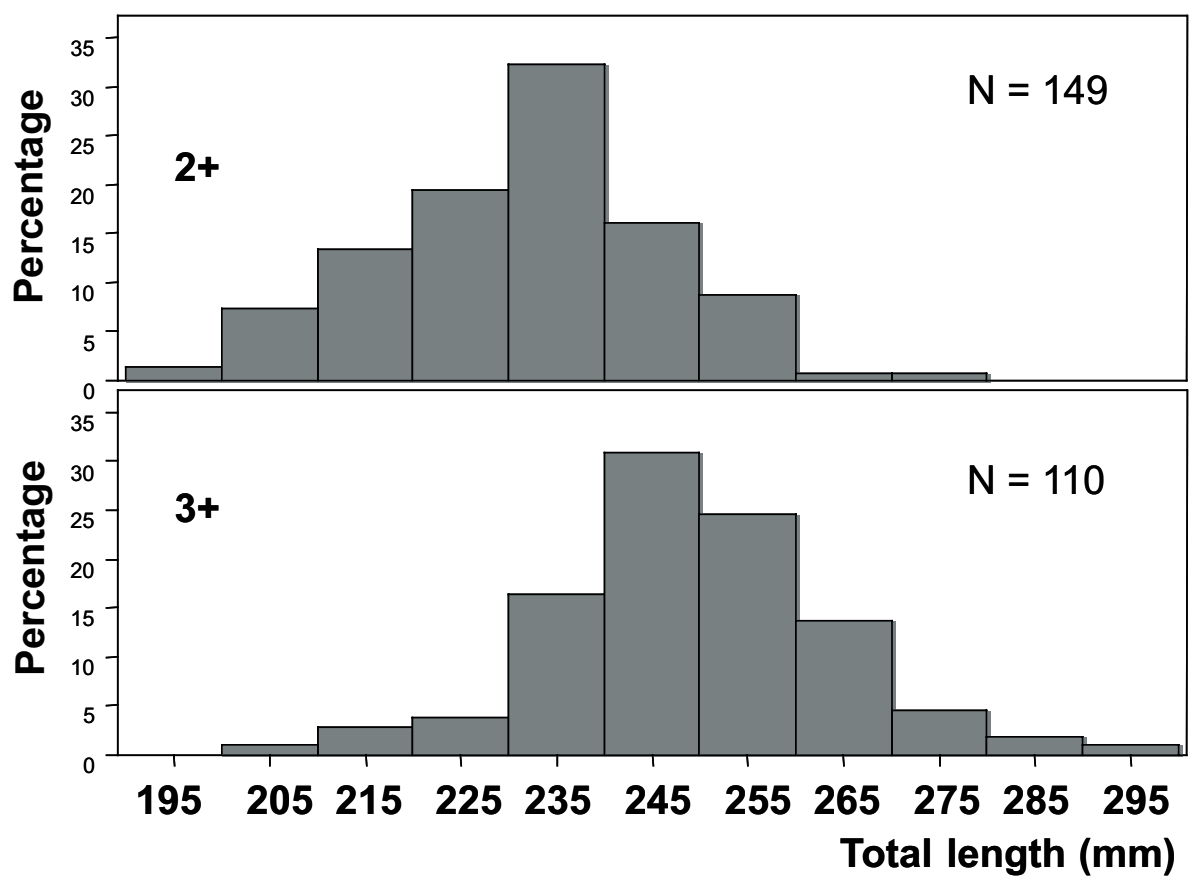

Figure 2

Length distributions of $2+$ and $3+$ trout for which otoliths were examined.

Figure 2

Distributions des longueurs des truites $2+$ et $3+$ dont les otolithes ont été examinés.

the two years ( $F$ test, $P<0.0001)$. The percentage of marked fish was $39.4 \%$ in 2002 and only $9.5 \%$ in 2003 .

This difference between the marking levels can be explained quite simply by the fact that the anglers predominantly tend to catch $2+$ (marked in 2000) and 3+ fish (marked in 1999). Thus in 2002 the fishery included both marked 2+ and 3+ fish. In 2003, there were $3+$ fish that had been marked in 2000 , but the 2+ fish had not been marked because they had been born in 2001. Consequently, in 2002, there were two age groups containing marked individuals, whereas in 2003 , only one group had been marked. This accounts for the difference observed, and indicates that the trout should have been sampled for the study from 2001, because catches already included marked 2+ trout at that time.

\section{Contribution of the marked fry to the catches per fishing sector}

The proportions of marked fish per sector were investigated for the years 2002 and 2003 combined, separate studies per year and per sector having been found to yield numbers that were too small to permit a valid statistical study.

Relatively large differences were found between the different sectors for the proportion of marked fish (Table III). The Kruskal-Wallis test showed that a significant part of the variability of these frequencies $(P<0.01)$ can be attributed to a sector effect. When the sectors were compared pairwise, we found that there were significantly different percentages between sectors 1 and 2 (Wilcoxon's test $\mathrm{P}<0.01$ ), and between sectors 2 and 4 (Wilcoxon's test $\mathrm{P}<0.01$ ). 


\section{Table III}

Percentage of marked fish in the catch samples of anglers for each sector of the study for the years 2002 and 2003 combined. In 2002, a total of 187 trout were caught, only 76 in 2003.

Tableau III

Pourcentage de poissons marqués dans les collectes des pêcheurs pour chaque secteur de la rivière. Les données de 2002 et 2003 ont été groupées. En 2002, 187 truites ont été capturées, seulement 76 en 2003.

\begin{tabular}{lcccccc}
\hline Sector & 1 & 2 & 3 & 4 & 5 & 6 \\
\hline $\begin{array}{l}\text { Number of fish } \\
\begin{array}{l}\text { Percentage of } \\
\text { marked trout }\end{array}\end{array}$ & 91 & 54 & 26 & 48 & 42 & 2 \\
\hline
\end{tabular}

\section{Contribution of the marked fry in the 1999 and 2000 cohorts}

Here the proportions of marked fish were not compared in terms of the year when they were caught, but according to the year of hatching (cohort). Comparison of the resulting two groups showed that the proportion of marked fish did not differ statistically (Wilcoxon's test $\mathrm{P}<0.5$ ): $33.7 \%$ of the fish were marked in the 1999 cohort (83 data; $\mathrm{Cl}_{95 \%}$ $23.3 \%-44.1 \%$ )., and $37.3 \%$ of the fish were marked in the 2000 cohort (142 data; $\mathrm{Cl}_{95 \%}$ $29.3 \%-45.4 \%)$.

\section{Age structure of the marked and unmarked fish in the 2002 catch}

More than $90 \%$ of the fish sampled for the study were $2+$ or $3+$ individuals. In 2002 , both these age groups included marked individuals, which validated this approach. There was no significant difference between the proportions in each cohort (Wilcoxon's test $\mathrm{P}>0.05$ ).

Marked and unmarked fish seemed to behave in the same way, had the same age profile, and therefore appeared to display the same temporal dynamics.

\section{DISCUSSION}

A first important result of the present study is that about $35 \%$ of the angler's catches were fish that had been previously released as fry, which is a relatively high proportion and much greater than what is seen after stocking with farmed fry (CHAMPIGNEULLE and CACHERA 2003; RICHARD, 1997). In addition, the populations of fish that had been stocked in this way displayed the same temporal dynamics as the individuals that had been derived from natural spawning; they did not grow more quickly or slowly, and they appeared to have similar catchability.

\section{Ecological yield}

From the fishing records kept voluntarily by about one half of the anglers, we can estimate that the annual catch amounts to at least 3,000 trout, all belonging to the study area. On the basis of this probably rather low estimation of the number of fish caught, we can estimate the yield of stocking on the entire study area. For the 2000 cohort this indicates a return of 29 adults caught per 1000 yolk-sac fry. This outcome is definitely better than the yields usually reported (between 8 and 12 catchable trout per 1000 fry released (RICHARD, 1997)). 
Furthermore, assuming the same hypothetical annual catch of 3000 trout, the relatively constant numbers of fish caught each year, and their age profile suggest that at the end of the fishing season the number of breeding adults remaining in the river is about the same as the number of fish that have been caught, i.e. about 3,000. In 1999, the anglers used 375 breeding adults in their hatchery, with 198 males and 177 females. In 2000 they had 301 breeding adults, 160 males and 141 females. Thus the anglers only took about $10 \%$ of the eggs from the natural environment. This estimated percentage should be compared to the fact that $39 \%$ of the fish caught in 2002 originated as fry released in 1999 or 2000. Handling the breeding stock can lead to some mortality, and this is to be added to the removal of eggs from the natural environment. However, since $25 \%$ of the breeding adults had in fact been obtained from anglers'catches, we can assume that these individuals would have been eliminated anyway, and using them largely compensates for any mortality resulting from the procedures used to harvest their eggs and milt.

\section{Genetic aspects}

ESTOUP et al (1998) have shown that there are major genetic subdivisions within the trout populations in the Vosges at locations as close from one another as a few kilometers. This has been confirmed in a study by GUYOMARD (2000). This indicates that each subpopulation has been subject to selection pressure, which has result in its adjustment to the local environmental characteristics. By using breeding stock belonging to the native strain, the anglers justifiably hope to achieve a better success rate that they could by using wild strains from other geographical origins or even farmed strains.

\section{Restoration of the environment and targeting the release of fry}

The sectors studied differed considerably and, as we have previously seen, the proportion of marked fish in the various sectors ranged from $16.7 \%$ to $50 \%$. This means that sectors that are very favourable for spawning would benefit little if at all from stocking, whereas sectors that have been much more disturbed owe a large proportion of their fish to stocking. For example in sector 4 , where the proportion of the fish caught to be marked was the lowest, the anglers have tried to create streams to provided additional spawning grounds. To do this, they have re-excavated disused irrigation channels (dating back to the Middle Ages and disused since the beginning of the twentieth century), which are known to be good spawning grounds. These streams are fed by a constant flow, and have the ideal water depth of about $12 \mathrm{~cm}$. This sector is very favourable for natural spawning, and so there is little or no point in stocking, and the practice could be discontinued without any impact on the number of fish caught. In contrast, in a highly anthropised sector, such as sector 2 , the percentage of marked fish reaches $50 \%$ as a result of the presence of numerous impassable barriers that prevent the adults from swimming upstream to their spawning grounds. If it is not possible to restore trout migration in this sector, stocking could have a major positive impact on the number of fish caught by anglers'.

\section{Natural risks}

These stocking practices to some extent protect anglers against a bad year in which the natural spawning grounds are destroyed by floods caused by melting snow. These sudden floods can have a devastating effect on the nursery streams, in which shallow water flows slowly over stones, by destroying the spawning grounds or washing the eggs out of the reeds. The fall in $\mathrm{pH}$ that also generally accompanies this type of flood can also lead to additional mortality in these rivers, where the water is already acidic.

Finally, one far from unimportant aspect of this amateur hatchery and stocking activities is their effect of creating social bonds between the members of the anglers'club who are involved in them, increasing a sense of stewardship for the environment and improving links between anglers and fisheries regulators. 


\section{CONCLUSION}

The purpose of this study was to estimate the contribution to trout catches of stocking with yolk-sac fry produced in an amateur hatchery from wild breeding adults belonging to the native strain. We conclude for this study area that stocking in this way had a beneficial impact on the stock of fish available for anglers in 2002 and 2003, although this conclusion is subject to the proviso that not all the sectors seem to need stocking. It is probable that the real usefulness of this practice is limited to the sectors that are unfavourable to natural spawning. Such management acts also require a very detailed understanding of the local environment in order to target the releases as appropriately as possible, and must be particularly well-managed with regard to regulatory aspects.

The populations into which fry were released and those produced by natural spawning seemed to display the same temporal dynamics. This contrasts with what was found by CHAMPIGNEULLE et al. (2002) in the context of stocking with trout in the early stages of the life cycle derived from farmed breeding stock.

It would be interesting to pursue the study of the same fishing sectors, by releasing marked fry only in specific sectors in order to investigate their dispersal and their fate, particularly in the sectors that are most unfavourable as a result of anthropisation of the water courses or because of the natural limits such as acidity of the water and the quantity of spawning grounds available.

\section{ACKNOWLEDGEMENTS}

We would like to thank the Fédération départementale des AAPPMA des Vosges, the anglers of the APPMA de Cornimont and its chairman Mr. Géhin, and all the anglers who contributed to this study, particularly by providing samples. We would also like to thank the agents of the CSP, the Technical Head of the Departmental Brigade, Mr. Biselx, and his team, the technicians of the Regional Direction, Mr. Mougenez and Mr. Collas, who helped to design and carry out the experiments and the fishing survey.

\section{REFERENCES}

BECKMAN D.W., SCHULZ R.G., 1996. A simple method for marking fish otoliths with alizarin compounds. Trans. Amer. Fish. Soc., 125, 146-149.

BOURRIE G., 1978. Acquisition de la composition chimique des eaux en climat tempéré. Application aux granites des Vosges et de la Margeride. Sci. Géol. Mémo. 52: $174 \mathrm{p}$.

CAUDRON A., CHAMPIGNEULLE A., 2002. Evolution spatio-temporelle de la contribution du repeuplement en truite (Salmo trutta L.) réalisé à des stades précoces dans le bassin amont du Fier (74). Bull. Fr. Pêche Piscic., 365/366, 455-469.

CAUDRON A., CHAMPIGNEULLE A., 2006. Technique de fluoromarquage en masse à grande échelle des otolithes d'alevins vésiculés de truite commune (Salmo trutta) à l'aide de l'Alizarine red s., Cybium, 30, 1, 65-72

CHAMPIGNEULLE A., ROJAS BELTRAN R., 2001. Le marquage des poissons. In: GERDEAUX D. (ed) Gestion piscicole des grands plans d'eau, 311-346, INRA, Paris.

CHAMPIGNEULLE A., DEGIORGI F., RAYMOND J.C., CACHERA S., 2002. Dynamique temporelle de la contribution du repeuplement en stades précoces de truite (Salmo trutta L.) dans la population en place et dans la pêche sur le Doubs franco-suisse. Bull. Fr. Pêche Piscic., 365/366, 471-485. 
CHAMPIGNEULLE A.., CACHERA S., 2003. Evaluation of large-scale stocking of early stages of brown trout, Salmo trutta, to angler catches in the French-Swiss part of the River Doubs. Fisheries Management and Ecology, 10, 79-85.

COWX I.G., 1994. Stocking strategies. Fisheries Management and Ecology, 1, 15-30.

ECKMANN R., CZERKIES P., HELMS C. and KLEIBS K., 1998. Evaluating the effectiveness of stocking vendace (Coregonus albula (L.)) eleutheroembryos by alizarin marking of otoliths. Archiv für Hydrobiologie, Special Issues Advances in Limnology 50, 457-463.

ESTOUP A., ROUSSET F., MICHALAKIS Y., CORNUET J.-M., ADRIAMANGA M. and GUYOMARD R., 1998. Comparative analysis of microsatellite and allozyme markers: a case study investigating microgeographic differentiation in brown trout (Salmo trutta). Molecular Ecology, 7, 339-353.

GUYOMARD R., 2000, Rapport final sur la caractérisation génétique de populationssources de truite commune destinées au repeuplement local dans le département des Vosges., 4 p.

INSIGHTFUL. 2001. S-Plus 6. Insightful Corporation.

KLEIN E., 2004, Gestion piscicole: intérêt des écloseries associatives de truite fario (Salmo trutta fario) sur la haute Moselotte (88). Conseil Supérieur de la pêche. Rapport d'étude. $37 \mathrm{p}$.

MOUGENEZ S., 2002. La Moselotte à Cornimont (88). Suivi de la population de truites par carnet de pêche. Conseil supérieur de la pêche. Synthèses annuelles: 1999, 7 p.; 2000, 9 p.; 2001, 9 p.

MOUGENEZ S., LUQUET J.F., BISELX A., 2000. Enquête sur la pêche de la truite sur la Moselotte à Cornimont (88). Bilan année 1998. Conseil supérieur de la pêche, $21 \mathrm{p}$.

NAGIEC M., CZERKIES P., GORYCZKO K., WITKOWSKI A. and MURAWSKA E., 1995. Mass-marking of grayling, Thymallus thymallus (L.), larvae by fluorochrome tagging of otoliths. Fisheries Management and Ecology, 2, 185-195.

NISBET N., 1958. Aperçu chimique sur quelques cours ruisseaux des Vosges: le Rabodeau et ses affluents. Annales Stat. Centrale Hydrobiol. Appl. 7, 270-280.

PROBST A., MASSABUAU J.C., PROBST J.L., FRITZ B., 1990. Acidification des eaux de surface sous l'influence des précipitations acides: rôle de la végétation et du substratum, conséquences pour les populations de truites. Le cas des ruisseaux des Vosges. CR Acad. Sci.Paris, 311, II, 405-411.

RICHARD A., 1997. Gestion piscicole: intervention sur les populations de poissons de repeuplement des cours d'eau salmonicoles. coll. Mise au Point, $241 \mathrm{p}$.

THIBAULT M., 1983. Les transplantations des Salmonidés d'eau courante en France, saumon atlantique (Salmo salar L.) et truite commune (Salmo trutta L.). C.R. Soc. Biogeogr., 59, 405-420.

TSUKAMOTO K., SEKI Y., OBA T., OYA M. and IWAHASHI M., 1989. Application of otolith to migration study of Salmonids. Physiology Ecology Japan, Special Volume 1, 119-140. 